\title{
Developing a Hospital Bed Distribution Model in Iran
}

\section{Anis Abbasi ${ }^{1}$, Amir Ashkan Nasiri Pour ${ }^{* 2}$, Seyyed Jamalodin Tabibi ${ }^{3}$, Pouran Raeisi ${ }^{4}$}

1. Faculty of Medical Sciences, Islamic Azad University, Tehran Science and Research Branch, Tehran, Iran

2. Department of Medical and Health Services Management, Faculty of Medical Sciences, Islamic Azad University, Tehran Science and Research Branch, Tehran, Iran

3. Department of Medical and Health Services Management, Faculty of Medical Sciences, Islamic Azad University, Tehran Science and Research Branch, Tehran, Iran

4. Department of Medical and Health Services Management, Faculty of Management and Medical Information, Iran University of Medical Sciences, Tehran, Iran

Article Type:

Original Article

\section{Article History:}

Received: 11 Aug. 2017

Revised: 7 Jul. 2018

Accepted:19 Aug. 2018

\section{*Correspondence:}

Amir Ashkan Nasiri

Pour,

Department of

Medical and Health

Services

Management, Faculty of Medical Sciences, Islamic Azad University, Tehran Science and Research Branch, Tehran, Iran nasiripour@srbiau.ac ir

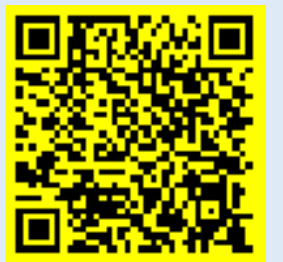

\begin{abstract}
Background and objectives: The development and distribution of hospital beds, regardless of effective factors, may downgrade equity in access to health services through imposing costs of inefficiency. This study aimed to develop a hospital bed distribution model in Iran in order to facilitate the optimal and cost-effective development and distribution of hospital beds.

Methods: This descriptive-analytical study with mixed-methods analysis was carried out during 2015-2016. The research population encompassed 345 managers and experts in the field of health, who were selected using multistage quota sampling method from five regions of Iran (north, south, center, west and east). A total of 23 experts were selected from each university, and a researcher-made questionnaire was used to collect data. Content Validity Ratio (CVR) was used to evaluate the questionnaire content and face validity. Cronbach's alpha coefficient and exploratory factor analysis with Varimax rotation were run as well to determine the questionnaire reliability and item consistency, respectively. For this purpose, AMOS version 20 and SPSS version 20 software were employed. To determine the fit of the model, the fit indices were also considered.

Results: Out of 51 effective factors included in the questionnaire in accordance with content validity, 23 items were confirmed by the experts. Exploratory factor analysis detected five organizational (seven components), economic (four components), social (six components), political (three components) and geographic (three components) factors as the main dimensions of hospital bed distribution, which could explain $70.745 \%$ of variance for all variables. The organizational and geographical dimensions had the highest (1.00) and lowest (0.16) influence on the hospital bed distribution. After running confirmatory factor analysis, two components of social and economic attributes with factor load of 0.46 in social dimension and efficiency and effectiveness of existing centers with factor load of 0.31 in the economic dimension were excluded from the model.

Conclusion: This study confirmed the hospital bed distribution model with five organizational, social, economic, political, and geographical dimensions, in which the organizational dimension with high explanatory power had the greatest impact on the hospital bed distribution. Therefore, this model seems efficient to be used as a comprehensive and appropriate method in making policies and decisions about the development and distribution of hospital beds.
\end{abstract}

Keywords: Bed, Hospital, Bed distribution, Rationing, Policy-making, Factor analysis

Copyright $($ 2018, Jorjani Biomedicine Journal has published this work as an open access article under the terms of the Creative Commons Attribution License (http://creativecommons.org/licenses/by-nc/4.0/) which permits noncommercial uses of the work while it is properly cited. 


\section{Introduction}

Appropriate, similar, and equal provision of health care services for different classes of society is one of the most significant issues in social welfare. Besides its special significance, it has a special complexity posed by its many dimensions and impact so that it makes the authorities and managers deal with large and complicated decisions in this regard (1). One of the major strategies to achieve social justice and equality in health systems is to provide easy, fair, and consistent access to medical and health needs in a society (2).

In this case, inequality in the geographical distribution of medical and health care resources makes access to health services difficult (3). On the other hand, increased number of treatable diseases, high cost of new equipment and technologies, and new therapies as well as enhanced level of expectations in the society and shortage of available resources makes accurate decisions a necessity when allocating resources to the health system (4).

Several factors affect access to health services, including three categories of structural (organization, health service providers, transportation system), financial (insurance coverage and public support, government), and individual (an individual's cultures, incomes, education, and Knowledge) factors, which play a key role in facilitating individuals' access to the services provided in the health centers (2).

In developing countries, the allocation of most resources is often unbalanced due to lack of information, skills and expertise in health planning $(5,6)$. In recent years, health expenditure growth has been much higher and more accelerated than the expenditure growth in other sectors, and this trend keeps raising (7). According to the World Bank's widespread studies on the share of public hospitals in consuming state-owned resources in developing countries, hospitals use about $50 \%$ to $80 \%$ of the total capital of the health sector (8). Moreover, the establishment and construction of a hospital requires large expenses. Hospital beds are one of the most important and valuable resources in the health care systems. Estimates have shown that about 800 million Tomans is spent on each hospital bed, which costs up to one billion Tomans in some large cities because of the high costs of lands (9). Given the nature of the medical sector with regard to the unconventional cost absorption, and given the aforementioned descriptions, there has always been a great gap between the available and required facilities. Due to resource constraints, the available resources are even less cost-effective in most cases (8).

Therefore, the lack of equal and fair allocation of hospital beds throughout Iran's provinces may lead to irreversible complications in addition to displacement of critically ill patients [6]. Consequently, the hospital bed distribution (as one of the resources of the health system) could be used as an indicator of service distribution (10 and 11).

Results of some studies, however, indicate that there are enough hospital beds in some regions in Iran and the problem is with the distribution and referral mechanisms and the provision of services $(6,12)$. According to these studies, although the mean ratio of hospital beds is 1.7 per 1000 persons, there are cities with six beds per 1000 persons as well as some other cities with less than $0.5 \%$ beds per 1000 persons (13). Zandian et al.'s study showed that the distribution of treatment and health care resources in Ardabil province, Iran, was asymmetrical and 
unbalanced and there was a slight modification during the study period to reduce resource inequality (14). Rashidian et al. (2008) concluded that the distribution of special infant beds was extremely unfair in Iran (15). Mostafavi's study reflected the unfair distribution of specialized physicians and hospital beds throughout West Azerbaijan province, Iran (16).

Considering the geographical maps of the special-care beds density, Tafighi et al. concluded that the density of the beds varies across different provinces (6). According to Rezai, the inequality in the distribution of health resources decreased in 2013 in comparison to 2006, even though the inequality still exists (17).

This lack of organization might be due to the fact that the existing model has failed to accurately estimate and specify the priorities of the country in accordance with the principles of the health economy. However, the improved use of these resources and access to health care services seems possible through identifying the factors and variables affecting the distribution of hospital beds.

The Ministry of Health and Medical Education, which is in charge of preserving, restoring, and improving health status among all individuals and their families, has always spared his effort to provide the fair and appropriate distribution of the hospital beds and to found hospitals; however, such decisions need thorough investigations based on field studies. Therefore, this study aimed to accurately and scientifically extract major factors affecting the appropriate distribution of hospital beds and to explain a model appropriate for Iran.

\section{Materials and Methods}

This descriptive-analytic study was carried out during 2015-2016 and used mixed methods design in four steps (namely review of the sources, validation of detected factors, exploratory factor analysis and confirmatory factor analysis, and model development) to achieve a suitable model for hospital beds distribution in Iran. This study was extracted from a Ph.D. thesis in Health Services Management approved by the ViceChancellor for Research at Islamic Azad University. Prior to the study, a written informed consent was obtained from the subjects and they were ensured of the confidentiality terms regarding their personal information.

In the first step, previous studies conducted in Iran and other countries on hospital bed distribution and its relevant factors were investigated through referring to libraries and reliable Persian (e.g., SID and Magiran) and non-Persian (e.g. PubMed and Scopus) databases. Based on the objectives of the study, a checklist of 67 factors affecting the hospital bed distribution in Iran and other countries was prepared. Then the extracted factors were reviewed by interviewing the experts and receiving their comments, according to which some repetitive cases were removed, similar cases were modified, and some new factors were added. Further, two questions were raised for this checklist, including "to what extent was the checklist compatible with the objectives of the study?" and "to what extent does it respond to Iran's situation?". Afterwards, the basic conceptual model with 51 factors was developed. In the second step in order to calculate the Content Validity Ratio (CVR), the extracted items were submitted to 15 experts of the field to provide comments on the items in the form of three options (i.e., necessary, useful but unnecessary, and unnecessary). Given that there were 15 experts, the minimum interrater score for the comprehensibility and presence of a concerned index in the final questionnaire was $\geq 0.49$ (18). In order to 
verify the questionnaire reliability, test-retest method was used as such the questionnaire was submitted to 30 qualified experts within two weeks. The data were collected and the reliability of the questionnaire was 0.88 . In the third step in order to determine the dimensions and variables of each dimension using exploratory factor analysis method, the confirmed factors were submitted to the experts as a 23-item questionnaires with a five-point Likert scale ranging from extremely high (5) to extremely low (1). The fourth step was used to confirm the identified factors for different dimensions and consequently to present and fit the final model.

The research population encompassed common available the hospital bed distribution models as information resources and experts in healthcare management, economics, and health policy. In the third and fourth steps of the study, it contained faculty members and Ph.D. students in the Medical and Health Services Management and Health Economics as well as managers and experts with academic knowledge about the health system, particularly the distribution of medical facilities and the medical classification system.

The sample size was calculated as the number of variables $(n=23)$ multiplied by 15 . In other words, 345 questionnaires were submitted to the participants in the study. Finally, 300 questionnaires were completed (with $87 \%$ response rate), of which14 questionnaires were excluded since they were not completed so that 276 questionnaires were further examined. Multistage quota sampling method was used, according to which the country was divided into five regions in the north, south, center, west, and east. For each region, there were three quotas; hence, three medical universities were randomly selected. In each cluster, 23 experts including professors and Ph.D. students in the field of medical and health services management and health economics as well as managers and experts who had academic experiences about the health system, especially the distribution of facilities and classification of medical and hospitalization services, were selected and received and completed the questionnaires.

To collect the data, the questionnaires were submitted in person in some accessible provinces. In other cases, some representatives were selected from each medical university and provided with necessary training on how to respond to the questionnaires.

Inclusion criteria were competence in the subject, a history of management activity in the health system, familiarity with the standards of hospitalization service allocation throughout the country, or being MA or $\mathrm{PhD}$ student in medical and health services management and health economy, and sufficient information about the research topic.

Finally, the central limit and dispersion indices (i.e., mean, standard deviation, and frequency distribution tables) were used to describe the data and exploratory factor analysis and confirmatory factor analysis methods were used to analyze the data, to extract the dimensions, and to determine the factors affecting the hospital bed distribution. Furthermore, fit indices were employed to determine the fit of the model. The collected data was analyzed by SPSS software version 20 and AMOS software version 20. 


\section{Results}

The study participants $(\mathrm{N}=276)$ in the study included 208 men (75\%) and 68 women (25\%). Regarding level of education, 101 (41\%) and 139 (47\%) persons held master's and $\mathrm{PhD}$ degrees and 36 (12\%) persons were PhD students. Moreover, 18 (7\%), 53 (19\%), 86 (31\%), 79 (29\%), and 40 (15\%) persons had a work experience of $\leq 5$ years, 5-10 years, 10-15 years, 15-20 years, and $\geq 20$ years, respectively. In terms of age, there were 30 persons $(11 \%)$ below 30 years of age, $67(24 \%)$ persons aged between 30 and 35 years, $86(31 \%)$ persons aged between 35 and 40 years, $55(20 \%)$ aged 40 to 45 years, and 38 (14\%) persons $\geq 45$ years of age.
After extracting factors affecting the optimal hospital bed distribution in the first step (67 factors), the number of items reduced to 51 factors after combination, deletion, and face validity examinations based on the interviews and experts' comments. Given that the minimum acceptable CVR for 15 participants was estimated to be 0.49 based on Lawshe's table in order to examine the content validity, 23 factors were considered to have impacts on the optimal hospital bed distribution in Iran. This would contribute to specifying the dimensions and presenting the model (Table 1).

Table 1. Factors Affecting the Optimal Hospital Bed Distribution and Their Content Validity

\begin{tabular}{|c|c|c|c|c|c|c|c|}
\hline ?a & Variables & CVR & $\begin{array}{l}\text { Accepted/ } \\
\text { Rejected }\end{array}$ & ? & Variables & CVR & $\begin{array}{l}\text { Accepted/ } \\
\text { Rejected }\end{array}$ \\
\hline 1 & Population & 100 & Accepted & 27 & $\begin{array}{l}\text { Average length of stay by } \\
\text { specialty }\end{array}$ & 47 & Rejected \\
\hline 2 & Population density & 60 & Accepted & 28 & $\begin{array}{l}\text { Existence of medical } \\
\text { education centers }\end{array}$ & 47 & Rejected \\
\hline 3 & $\begin{array}{l}\text { Culture, religion, and } \\
\text { language in the } \\
\text { concerned region }\end{array}$ & 33 & Rejected & 29 & $\begin{array}{l}\text { Urgency and complexity of } \\
\text { service delivery }\end{array}$ & 33 & Rejected \\
\hline 4 & $\begin{array}{l}\text { Gender and age } \\
\text { distribution of the } \\
\text { sample }\end{array}$ & 73 & Accepted & 30 & Human service providers & 47 & Rejected \\
\hline 5 & $\begin{array}{l}\text { Population growth } \\
\text { rate }\end{array}$ & 87 & Accepted & 31 & $\begin{array}{l}\text { Inter-hospital } \\
\text { communications network }\end{array}$ & 33 & Rejected \\
\hline 6 & $\begin{array}{l}\text { Geographical status of } \\
\text { the region }\end{array}$ & 60 & Accepted & 32 & $\begin{array}{l}\text { Comprehensiveness and } \\
\text { acceptability of health care } \\
\text { provision }\end{array}$ & 20 & Rejected \\
\hline 7 & $\begin{array}{l}\text { Geographical access } \\
\text { to referral levels }\end{array}$ & 100 & Accepted & 33 & Transportation facility & 33 & Rejected \\
\hline 8 & $\begin{array}{l}\text { Frequency of cities, } \\
\text { towns and villages up } \\
\text { to } 60 \mathrm{~km} \text { from the } \\
\text { hospital }\end{array}$ & 87 & Accepted & 34 & $\begin{array}{l}\text { Bed to population ratio in } \\
\text { each region (Ratio of bed to } \\
1000 \text { persons) }\end{array}$ & 60 & Accepted \\
\hline 9 & $\begin{array}{l}\text { Urban and rural } \\
\text { traffic networks }\end{array}$ & 33 & Rejected & 35 & Hospital ownership & 73 & Accepted \\
\hline 10 & $\begin{array}{l}\text { Natural status of the } \\
\text { region (mountainous, } \\
\text { forest, coastal, } \\
\text { weather conditions, } \\
\text { etc.) }\end{array}$ & 47 & Rejected & 36 & $\begin{array}{l}\text { Upstream documents and } \\
\text { policies }\end{array}$ & 100 & Accepted \\
\hline 11 & $\begin{array}{l}\text { Mortality rates and } \\
\text { other vital indices }\end{array}$ & 100 & Accepted & 37 & $\begin{array}{l}\text { Bias and } \\
\text { acceptance }\end{array}$ & 87 & Accepted \\
\hline
\end{tabular}




\begin{tabular}{|c|c|c|c|c|c|c|c|}
\hline 12 & $\begin{array}{l}\text { Illiteracy and literacy } \\
\text { rates }\end{array}$ & 47 & Accepted & 38 & Power pressure & 87 & Accepted \\
\hline 13 & $\begin{array}{l}\text { Socio-economic } \\
\text { attributes }\end{array}$ & 87 & Accepted & 39 & $\begin{array}{l}\text { Direct and indirect medical } \\
\text { and health care costs }\end{array}$ & 47 & Rejected \\
\hline 14 & $\begin{array}{l}\text { Number of referrals } \\
\text { by specialized beds } \\
\text { (based on } \\
\text { retrospective study) }\end{array}$ & 73 & Accepted & 40 & Per capita income & 33 & Rejected \\
\hline 15 & $\begin{array}{lr}\begin{array}{l}\text { Patient rate } \\
\text { concerned the } \\
\text { (number region } \\
\text { hospitalized patients }\end{array} \\
\text { per thousand persons } \\
\text { within a year) }\end{array}$ & 73 & Accepted & 41 & Hospital scale & 33 & Rejected \\
\hline 16 & $\begin{array}{l}\text { Comparing } r \text { the } \\
\text { number of referrals } \\
\text { per } 1000 \text { persons of a } \\
\text { region, a province, } \\
\text { and a country } \\
\text { (acceptance rate of } \\
\text { patients). }\end{array}$ & 47 & Rejected & 42 & $\begin{array}{l}\text { Economy of size } \\
\text { (Minimizing service costs } \\
\text { by preventing the } \\
\text { establishment of small or } \\
\text { single medical units) }\end{array}$ & 47 & Rejected \\
\hline 17 & $\begin{array}{l}\text { Basic epidemiological } \\
\text { data }\end{array}$ & 33 & Rejected & 43 & $\begin{array}{l}\text { Economy of domain } \\
\text { (maximizing high-risk } \\
\text { patients treated in a medical } \\
\text { unit to accumulate expertise } \\
\text { and experience and improve } \\
\text { the consequences for } \\
\text { patients) }\end{array}$ & 33 & Rejected \\
\hline 18 & $\begin{array}{l}\text { Prevalence and } \\
\text { burden of disease }\end{array}$ & 100 & Accepted & 44 & $\begin{array}{l}\text { Efficiency and effectiveness } \\
\text { of service provider centers }\end{array}$ & 60 & Accepted \\
\hline 19 & $\begin{array}{l}\text { Major causes of } \\
\text { mortality (pregnant } \\
\text { women, } \\
\text { cardiovascular } \\
\text { diseases, high } \\
\text { accident rates, and so } \\
\text { on) }\end{array}$ & 73 & Accepted & 45 & $\begin{array}{l}\text { Existence of financial } \\
\text { resources }\end{array}$ & 100 & Accepted \\
\hline 20 & $\begin{array}{l}\text { Vulnerable population } \\
\text { size }\end{array}$ & 20 & Rejected & 46 & $\begin{array}{l}\text { Existence of appropriate } \\
\text { physical space and facilities }\end{array}$ & 100 & Accepted \\
\hline 21 & $\begin{array}{ll}\text { Vulnerability } & \text { to } \\
\text { common diseases in } \\
\text { the region }\end{array}$ & 33 & Rejected & 47 & $\begin{array}{l}\text { Existence and number of } \\
\text { service provider centers } \\
\text { (including urban and rural } \\
\text { health centers and regional } \\
\text { hospitals) }\end{array}$ & 47 & Rejected \\
\hline 22 & Life expectancy & 47 & Rejected & 48 & $\begin{array}{l}\text { Number of industrial } \\
\text { centers, factories, and } \\
\text { producers, agricultural and } \\
\text { farm areas, and business } \\
\text { centers }\end{array}$ & 20 & Rejected \\
\hline 23 & $\begin{array}{ll}\text { Inpatient } & \text { and } \\
\text { outpatient rates }\end{array}$ & 47 & Rejected & 49 & Employment rate & 33 & Rejected \\
\hline 24 & Hospital Performance & 100 & Accepted & 50 & Economic inflation rate & 47 & Rejected \\
\hline
\end{tabular}




\begin{tabular}{|l|l|l|l|l|l|l|l|}
\hline & $\begin{array}{l}\text { Indicators (i.e., bed } \\
\text { occupancy rate, bed } \\
\text { occupancy } \\
\text { percentage, average } \\
\text { length of stay) }\end{array}$ & & & & & & \\
\hline 25 & $\begin{array}{l}\text { Optimal bed } \\
\text { occupancy rate of } \\
70 \%-85 \%\end{array}$ & 20 & Rejected & 51 & $\begin{array}{l}\text { Interest rate for health } \\
\text { insurance investment }\end{array}$ & Rejected \\
\hline 26 & Wait list and time & 73 & Accepted & & & & \\
\hline
\end{tabular}

After calculating the primary matrix for the concerned factors, it was found that five factors were $\geq 1$ and explained $70.745 \%$ of the variance in all variables. In other words, there were five factors reflecting $70.445 \%$ of variation in eigenvalues for each of the tested indices (Table 2).

Table 2. Total Variance Explained by the Five Factors before and after Rotation

\begin{tabular}{|l|l|l|l|l|l|l|}
\hline \multirow{2}{*}{ Factors } & \multicolumn{2}{|l|}{ Rotation Sums of Squared Loadings } & \multicolumn{2}{l|}{ Rotation Sums of Squared Loadings } \\
\cline { 2 - 7 } & Eigenvalues & \%Variance & $\begin{array}{l}\text { Cumulative } \\
\text { percentage }\end{array}$ & Eigenvalues & \%Variance & $\begin{array}{l}\text { Cumulative } \\
\text { percentage }\end{array}$ \\
\hline First factor & 7.705 & 33.5 & 33.5 & 5.463 & 24.535 & 24.535 \\
\hline Second factor & 3.231 & 14.049 & 47.549 & 3.521 & 15.31 & 39.845 \\
\hline Third factor & 2.246 & 9.765 & 57.314 & 2.717 & 11.814 & 51.659 \\
\hline Fourth factor & 1.747 & 7.597 & 64.919 & 2.395 & 10.431 & 62.072 \\
\hline Fifth factor & 1.342 & 5.834 & 70.745 & 1.995 & 8.674 & 70.745 \\
\hline
\end{tabular}

Table 3 presents the matrix of the components and the factor loading of variables after the Varimax rotation.

Table 3. Factor Loads of Variables Affecting the Optimal Hospital Bed Distribution

\begin{tabular}{|l|l|l|l|l|l|}
\hline \multirow{2}{*}{ Variable } & \multicolumn{2}{l|}{ Factors } \\
\cline { 2 - 6 } & $\begin{array}{c}\text { Organizati } \\
\text { onal }\end{array}$ & Social & Economic & Political & Geographical \\
\hline $\begin{array}{l}\text { Upstream documents and } \\
\text { policies }\end{array}$ & & & & 0.848 & \\
\hline $\begin{array}{l}\text { Population size } \\
\text { Frequency of cities, } \\
\text { towns and villages up to } \\
60 \text { km from the hospital }\end{array}$ & 0.661 & & & \\
\hline $\begin{array}{l}\text { Bias and political } \\
\text { acceptance age }\end{array}$ & & & & 0.817 \\
\hline $\begin{array}{l}\text { Gender and } \\
\text { distribution of population }\end{array}$ & 0.819 & & 0.826 & \\
\hline $\begin{array}{l}\text { Number of referrals by } \\
\text { specialized beds (based } \\
\text { on retrospective study) }\end{array}$ & 0.845 & & & & \\
\hline
\end{tabular}




\begin{tabular}{|c|c|c|c|c|c|}
\hline $\begin{array}{l}\text { Bed to Population ration } \\
\text { in each region (Ratio of } \\
\text { bed to } 1000 \text { persons) }\end{array}$ & 0.648 & & & & \\
\hline $\begin{array}{ll}\text { Hospital } & \text { Performance } \\
\text { Indicators } & \text { (i.e., bed } \\
\text { occupancy } & \text { rate, bed } \\
\text { occupancy } & \text { percentage, } \\
\text { average length of stay) }\end{array}$ & 0.627 & & & & \\
\hline $\begin{array}{l}\text { Prevalence and burden of } \\
\text { disease }\end{array}$ & 0.845 & & & & \\
\hline $\begin{array}{lr}\begin{array}{lr}\text { Major } & \text { causes } \\
\text { mortality } & \text { of } \\
\text { women, } & \text { cardiovascular } \\
\text { diseases, } & \text { high } \\
\text { rates, and so on) }\end{array} \\
\end{array}$ & 0.920 & & & & \\
\hline Power pressure & & & & 0.903 & \\
\hline $\begin{array}{lr}\text { Efficiency } & \text { and } \\
\text { effectiveness of } & \text { service } \\
\text { provider centers }\end{array}$ & & & 0.520 & & \\
\hline Wait list and time & 0.931 & & & & \\
\hline Hospital ownership & & & 0.895 & & \\
\hline $\begin{array}{l}\begin{array}{l}\text { Geographical status of } \\
\text { the region }\end{array} \\
\end{array}$ & & & & & 0.712 \\
\hline $\begin{array}{l}\text { Patient rate in the } \\
\text { concerned region } \\
\text { (number of hospitalized } \\
\text { patients per thousand } \\
\text { persons within a year) }\end{array}$ & 0.926 & & & & \\
\hline Population density & & 0.742 & & & \\
\hline $\begin{array}{l}\text { Geographical access to } \\
\text { referral levels }\end{array}$ & & & & & 0.867 \\
\hline Population growth rate & & 0.671 & & & \\
\hline $\begin{array}{l}\text { Mortality rates and other } \\
\text { vital indices }\end{array}$ & & 0.525 & & & \\
\hline \begin{tabular}{|lrr} 
Existence & of appropriate \\
physical & space & and \\
facilities & (e.g., & land \\
donation) & & \\
\end{tabular} & & & 0.781 & & \\
\hline $\begin{array}{l}\begin{array}{l}\text { Existence of financial } \\
\text { resources }\end{array} \\
\end{array}$ & & & 0.892 & & \\
\hline $\begin{array}{l}\text { Socio-economic } \\
\text { attributes }\end{array}$ & & 0.722 & & & \\
\hline
\end{tabular}

To detect the outliers, the box plot was used. First, a box plot was drawn for economic, socio-cultural, organizational, geographical and political dimensions and the outliers were identified in each dimension. In order to manage the outliers in each dimension, the researchers adopted the following measures:
If the outlier were created by mistyping, it would be replaced with an integer. Furthermore, if the outlier were associated with the unreal numbers reported by the study participants, it would be replaced by median. The standard deviation of the population was used to remove non-significant cases. To do 
so, the standard deviation of the population was calculated for each sample in Excel document. In the present study, the population's standard deviation values for all samples were $\geq 0.3$; hence, no sample was excluded.

Kurtosis for each questionnaire item ranged between -3 and +3 while their skewedness was between -5 and +5 , indicating that all the items in the questionnaire were normally distributed.

Considering the critical ratio and the significance level of 0.01 , all the items were meaningful with a probability level of $99 \%$. This mean that all items of the relevant dimensions with a probability level of $99 \%$ had significant correlations; hence, they met the first criterion to be included in the model. For example, with a probability level of $99 \%$, there was a significant relationship between patient wait lists and time (with a critical ratio of 25.445 , an error of 0.47 , and a significance level of 0.01), patient rate in the concerned region (with a critical ratio of 24.839 , an error of 0.47 , and a significance level of 0.01 ), and prevalence and burden of disease (with a critical ratio of 19.012, an error of 0.56 , and a significance level of 0.01 ) with organizational dimension, hospital ownership (with a critical rate of 5.200, an error of 0.56 and a significance level of 0.01 ) and economic dimension. According to the standard table, if the factor load exceeds the minimum acceptable standard (0.5), it will not be excluded from the model; therefore, the factor loads for all the questions (except for Item 5 in social dimension (socio-economic attributes) and Item 1 in economic dimension (efficiency and effectiveness of service provider centers)) were $\geq 0.5$, and they remained in the model.

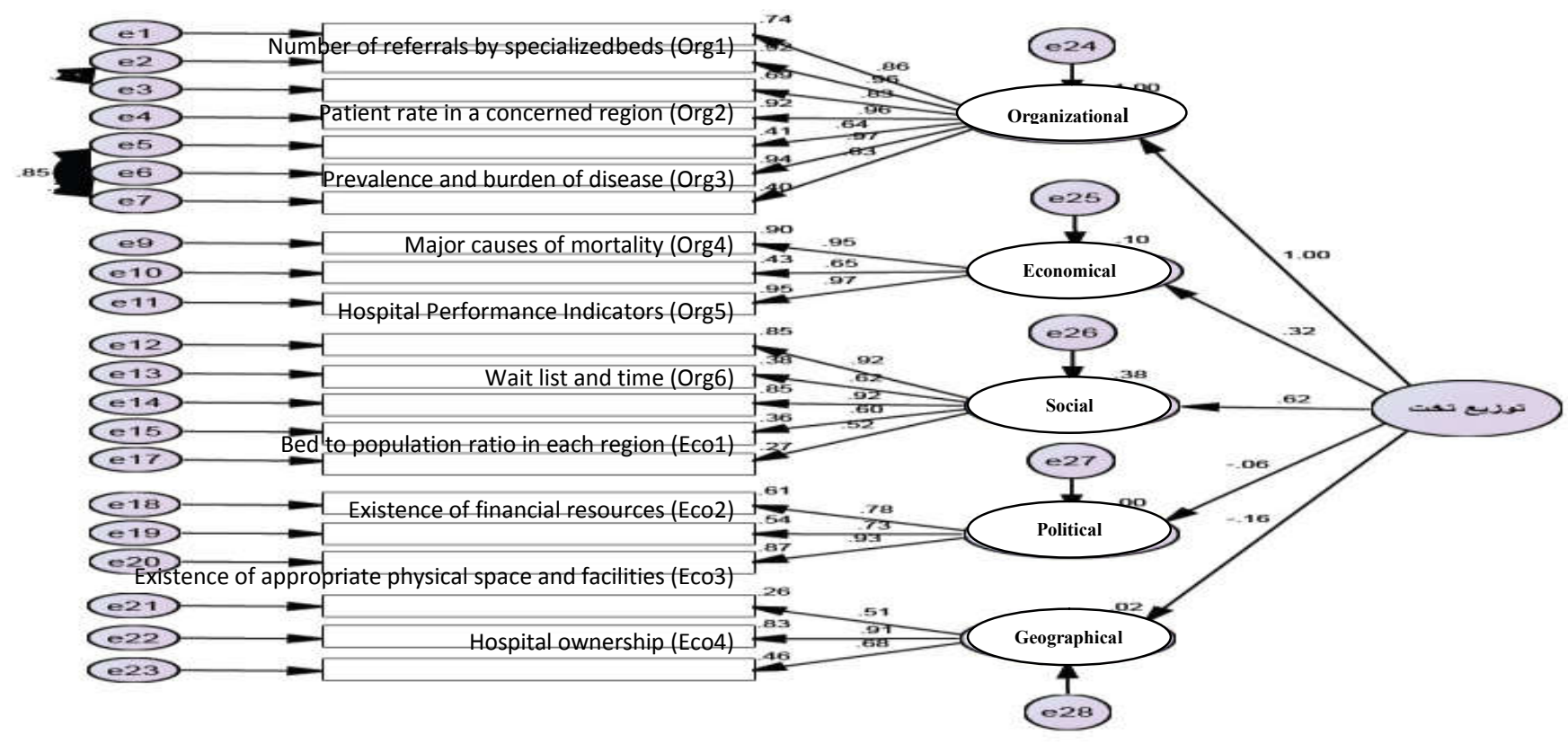

Figure 1. Hospital Bed Distribution Model in Iran 
Among the items associated with the organizational dimension, Item 6 (wait list and time) and Item 7 (bed to population ratio) had the highest (0.97) and the lowest (0.63) correlation coefficients, respectively. In economic dimension, Item 4 (hospital ownership) had the highest correlation coefficient (0.97) and Item 3 (physical space and facilities) had the lowest correlation coefficient (0.65). In the socio-cultural dimension, the highest correlation coefficient (0.92) was reported for Items 1 and 3 (age and gender distribution of population and mortality rates and other vital indices) and Item 6 (population density) had the lowest correlation coefficient $(0.52)$. In the political dimension, Items 3 (power pressure) and two (bias and political acceptability) had the highest (0.93) and lowest (0.73) correlation coefficients, respectively. Finally, in the geographical dimension, Item 2 (Geographical access to referral levels) had the highest correlation coefficient (0.91) and Item 1 (geographical status of the region) had the lowest correlation coefficient (0.51) (Fig. 1). Given that a minimum of three fit indices should be within the acceptable range in order for a model to be validated, the model proposed in this study was approved (Table 4).

Table 4. Fit Indices of Confirmatory Factors Analysis for Factors Affecting the Optimal Hospital Bed Distribution

\begin{tabular}{|l|l|l|l|l|}
\hline Indices & Fit indices & $\begin{array}{l}\text { Allowed } \\
\text { Limit }\end{array}$ & $\begin{array}{l}\text { Basic } \\
\text { model }\end{array}$ & $\begin{array}{l}\text { Modified } \\
\text { Model }\end{array}$ \\
\hline \multirow{5}{*}{ Absolute } & $\begin{array}{l}(\chi 2 / D F) \\
\text { CMIN/DF }\end{array}$ & $<0.3$ & 4.417 & 2.308 \\
\cline { 2 - 5 } & RMSEA & $<0.08$ & 0.111 & 0.069 \\
\cline { 2 - 5 } & GFI & $>0.8$ & 0.784 & 0.878 \\
\cline { 2 - 5 } & AGFI & $>0.8$ & 0.729 & 0.840 \\
\hline \multirow{5}{*}{ Economic } & PNFI & $>0.5$ & 0.709 & 0.770 \\
\hline \multirow{5}{*}{ Comparative } & NFI & $>0.9$ & 0.816 & 0.919 \\
\cline { 2 - 5 } & RFI & $>0.9$ & 0.788 & 0.903 \\
\cline { 2 - 5 } & IFI & $>0.9$ & 0.851 & 0.952 \\
\cline { 2 - 5 } & TLI & $>0.9$ & 0.828 & 0.943 \\
\cline { 2 - 5 } & CFI & $>0.9$ & 0.850 & 0.952 \\
\hline
\end{tabular}

Since CR is $>0.7$ for all dimensions, construct validity is confirmed. Meanwhile, $\mathrm{CR}$ is larger than AVE and AVE is larger than 0.5; therefore, the convergence validity criterion is also met for all dimensions. Further, since AVE is larger than USA and MSV, differential validity is also observed for all dimensions affecting the optimal hospital bed distribution (Table 5). 
Table 5. Reliability and Validity of Factors Affecting the Optimal Hospital Bed Distribution

\begin{tabular}{|l|l|l|l|l|l|l|l|l|l|}
\hline & CR & AVE & MSV & ASV & $\begin{array}{l}\text { Geograp } \\
\text { hical }\end{array}$ & $\begin{array}{l}\text { Organiz } \\
\text { ational }\end{array}$ & $\begin{array}{l}\text { Econom } \\
\text { ic }\end{array}$ & $\begin{array}{l}\text { Sociocult } \\
\text { ural }\end{array}$ & $\begin{array}{l}\text { Politica } \\
\text { l }\end{array}$ \\
\hline $\begin{array}{l}\text { Geographi } \\
\text { cal }\end{array}$ & 0.859 & 0.671 & 0.074 & 0.026 & 0.819 & & & & \\
\hline $\begin{array}{l}\text { Organizati } \\
\text { onal }\end{array}$ & 0.945 & 0.716 & 0.381 & 0.128 & -0.063 & 0.846 & & & \\
\hline Economic & 0.902 & 0.760 & 0.104 & 0.058 & 0.272 & 0.323 & 0.872 & & \\
\hline $\begin{array}{l}\text { Sociocultur } \\
\text { al }\end{array}$ & 0.847 & 0.540 & 0.381 & 0.112 & 0.088 & 0.617 & 0.210 & 0.735 & \\
\hline Political & 0.752 & 0.514 & 0.25 & 0.017 & 0.135 & -0.158 & 0.095 & -0.131 & 0.717 \\
\hline
\end{tabular}

\section{Discussion}

The hospital bed distribution model in Iran, with 5 dimensions and 21 relevant variables, provides a means for policymakers and health care managers in planning for the hospital bed development. In this research, one of the most effective dimensions of bed distribution model is organizational dimension, in which the subcomponent of patient's wait list and time is of paramount significance. In the study by Ataolahi et al., the average wait time for using the bed (from the time a patient requests for services to the time the service is provided) was considered as an essential factor in hospital allocations (19). Findings of a study entitled "Impact of delayed admission to intensive care units on mortality of critically ill patients: a cohort study" by Cardoso et al., indicated that 326 clinical referrals were not admitted due to the hospital bed shortages and that the wait time for clinical admissions was long (20). Another influential component in this dimension was patient rate in a concerned region, i.e. the population's exploitation from the bed. According to the results of the research by Goudarzi et al., entitled "The modeling of hospital beds forecasting in IR of Iran," although the hospital bed shortages in a region could severely reduce access and equity to health services, the development of hospital beds, regardless of the patient acceptance capacity, could lead to further decrease in the health equity index through imposing costs of inefficiency. This finding is consistent with the results in the current study (12).

The bed to population ratio is commonly regarded as an indicator to compare access to hospital beds in different areas at national and international levels, and its value is usually dependent on the development status of the health systems and the service delivery models and health policies in each community. Goudarzi et al. introduced the ratio as one of the effective criteria in predicting the number of required beds (12). This claim is partly in accordance with the results of the present study because the index was introduced as one of the indices with low effectiveness in the proposed model. Before distributing and allocating beds to different regions, the frequency of referrals to different specialties should first be considered as such with an appropriate understanding of the needs in different regions, the optimal allocation and distribution of resources, including the hospital beds, is facilitated. Ataolahi et al. carried out their study in Shahid Mohammadi Hospital in Bandar Abbas, Iran, and observed shortages of 
hospital beds in ICU, CCU, orthopedic, and internal wards and a surplus of hospital beds in internal emergency, neurology, burn, and nerve surgery wards (19). The social dimension was detected as the second most effective dimension in the proposed hospital bed distribution model, and was an effective component of the number, growth rate, age, and gender distribution and population density. Jamali et al., introduced the population of a region as one of the major factors in locating hospitals and allocating health and medical facilities. Moreover, the results of this study presented no balance between population density and number of hospitals in Tabriz, Iran (21). Ahadnejad et al. mentioned that the residential-demographic information layer is one of the significant layers with a relative weight of 0.2 in locating hospitals (22). In Australia's hospital construction projects, the structures of age and population in a region are primary factors in the hospital bed allocation (23). Aghamohamadi et al. suggested that shifts in the diseases patterns toward chronic diseases as well as shifts in the population age and gender structure toward aging in Iran would have a great influence on the future demands for hospital beds (24). According to Schofield and Earnest's study, aging would increase the demand for beds up to 70-130 percent by 2050 (25). Like the previous studies, the abovementioned criteria in the present study are also important factors in the hospital bed distribution model.

The economic dimension was the third most influential dimension in the proposed model, which encompassed the indices such as hospital ownership, financial resources, availability of facilities, and others. When establishing a hospital in a region, it should be considered whether the hospital ownership fits to the regional residents' financial capability. In terms of economic access, travel costs, fees and services should be affordable to individuals, families and society. Additionally, investment costs and the physical and environmental attributes are one of the important factors in locating hospitals and allocating health and medical facilities (13). Maher et al. observed high inequality in the distribution of health costs among rural households in Iran's provinces. Governments should reduce such an inequality by increasing health facilities in distant areas and by allocating financial grants (13). Lowincome households pay about 40 percent of their trivial income for health care services while affluent households approximately spend 9 percent of their income on health care costs (26). Out of 10 hospitals in District 11 in Tehran, six hospitals are privately held and are mainly established to bring financial profits; therefore, necessary measures should be adopted to provide public services in the region (22). The use of private-public partnership (PPP) investment models in the health sector, if the grounds are available, would be an appropriate solution for Iran's hospital sector (7).

Geographical and political dimensions with the least regression weight were the fourth and fifth dimensions included in the proposed model. Power pressure and upstream documents and policies were among the most effective indices in the political dimension. Major administrators and policymakers, such as the Ministry of Health and the Islamic Consultative Assembly, should make their health policies and, consequently, the health resources allocation and distribution policies in line with the macroeconomic objectives of the system since the adoption and implementation of a policy 
affects the various pillars of the health system. For example, changing the number of beds would change the resources in each sector, including manpower, budget, and other resources (11). According to the findings of Zahediasl's research (1996), above $45 \%$ of the beds in the private sector are placed in Tehran while the share of Ilam, Bushehr, Chaharmahal and Bakhtiari, Zanjan, Semnan, Sistan and Baluchestan, Kurdistan and Boyer Ahmad was zero in 1996 (27). The results of this study reflects the problems with either macro policies or the implementation of the adopted policies. Considering that Tehran is the capital of Iran and enjoys power pressure, its facilities seems to exceed those in other regions of the country.

Among the variables affecting the geographical dimension is geographical location and access to referral levels. Parsa Moghadam et al. studied the optimal location of urban hospitals using GIS and determined the optimal location for the construction of a hospital in Ardebil in order to improve individuals' access to health services (28). According to Shafii et al., there are 34 thirdlevel hospitals for maternal and infant care (referral) in 22 geographical regions of Tehran with six hospitals being located 500 meters apart from each other, 29 hospitals being at a distance of 3000 meters or less away from each other, and four hospitals having a distance of more than 3000 meters from their adjacent hospitals. The researchers stated that all inequalities could be due to a lack of planning and inconsideration of health and geographical issues as well as mere consideration of economic issues when selecting a site to establish a hospital as a majority of hospitals in Tehran are located in the central and northern regions of Tehran (29).

In their research, Khabiri et al. found that the highest frequency of childbirths on roads
(33.3\%) occurred in Tehran province. Despite the fact that most hospitals and hospital beds are concentrated in Tehran province, the disproportionate distribution of hospital beds in different regions along with the heavy traffic has led to the occurrence of such childbirths (30). Hospitals located on downtown, narrow and crowded streets cause problems such as lack of prompt and timely access and noise pollution posed by traffic congestion, resulting in discomfort for patients (31). It is recommended that hospitals that are far away from other hospitals and individuals covered by the hospital are far away from other hospitals offer a variety of services to meet a greater number of needs for the covered ones (32).

\section{Conclusion}

As the lack of hospital beds in a region can greatly decrease equality and access to health services, hospital bed development and distribution, regardless of effective factors, may downgrade equity in access to health services through imposing costs of inefficiency. According to the results of the current research, it could be concluded that the model proposed in this research has provided a means for policymakers in the health system to improve the hospital bed distribution even though further accurate information over different time periods are required for this model. This model would help the Ministry of Health and Medical Education to gain a thorough understanding of the issues with a greater impact on the hospital bed development and distribution in order to plan, implement and manage the issue. Hospitals should also increase their efficiency not only to improve the quality of their services but also to promote satisfaction among their clients. The Ministry of Health and Medical Education is thus recommended to consider the effective dimensions and 
factors detected in this model and to include them in the Iran's health development document that is being compiled. To implement the model, a comprehensive information system in the healthcare sector should be set up to record effective indices such as the percentage of service benefits, patient immigration, and others in order to plan and approve future macro policies of the health system through using such information.

\section{Acknowledgements}

Not applicable

\section{Declarations}

\section{Funding source(s)}

Hereby, we extend our gratitude to the vice-chancellor of the Islamic Azad University, Tehran Science and Research Branch, and to the participants in the study.

(No: 50508, date: 09/11/2017)

\section{Conflict of interest}

We declare that we have no financial or non-financial conflicts of interest related to the subject matter or materials discussed in the article. 


\section{References}

1. Sharifzadegan1 MH, Mamdohi MR, Lavi m. A P- median-model-based Analysis of Spatial Inequality in Accessibility to Public Health Care Intended for Urban Health Development in Isfahan City. Social Welfare. 2010; 10(37):26585.

2. Khayatan M NA, Amini M, Mohammadnezhad SM. Factors affecting people access to services from employees viewpoints in selected health care centers in Rey city. Payavard-Salamat. 2010; 4(3):18-27.

3.Ramandi SD, Niakan L, Aboutorabi M, Noghabi JJ, Khammarnia M, Sadeghi A. Trend of Inequality in the Distribution of Health Care Resources in Iran. Galen Medical Journal. 2016; 5(3):122-30.

4. Amerioon A, Mesgarpour Amiri M, Anabad A. Rate of inequality in kidney transplantation services access in Iran. Journal of Critical Care Nursing. 2010; 3(3):15-6.

5. Petrie D, Tang KK. A rethink on measuring health inequalities using the Gini coefficient. 2008.

6. Tofighi S, Meskarpour Amiri M, Ameriuon A, naseri $\mathrm{H}$. Equity in distribution of intensive care beds in Iran with Gini coefficient and Lorenz curve approach. yafte. 2011; 12 (2)

7. Nosrati M, Sadeghi H, Abdoli G, AgheliKohnehshahri L. Applying Public-Private Partnership Investment Model in Health: Assessment of Hospital Readiness in Iran. 3. 2013; 1 (2): 137-128

8. Ebadi F, Ansari H, Rezapoor A. Study of Daily Bed Occupancy Costs and Performance Indexes in Selected Hospitalat of Iran University of Medical Sciences in 1381. jha. 2005; 7 (18): 3744

9. asgari $\mathrm{H}$. The Estimation of Cost Function in Ilam Hospitals (2003-2012). sjimu. 2014; 22 (4): 190-198

10. Lai D, Huang J, Risser JM, Kapadia AS. Statistical properties of generalized Gini coefficient with application to health inequality measurement. Social Indicators Research. 2008; 87(2):249-58.
11. Miao C-x, Zhuo L, Gu Y-m, Qin Z-h. Study of large medical equipment allocation in Xuzhou. Journal of Zhejiang University-Science B. 2007; 8(12):881-4.

12. Goudarzi S, Mazhari S, Moayeri F. The Modeling of Hospital Beds Forecasting in IR of Iran. Iranian Red Crescent Medical Journal. 2011; 2011(7, Jul):510-1.

13. Maher A, Marzang $S$, Hosseini $S \mathrm{M}$. Correlation between Distribution of Hospital Inpatient Beds and Households expenditure in Iran. hbrj. 2016; 2 (3): 275-287

14. Zandiyan H, Ghiasvand H, Nasimi DR. Measuring inequality of distribution of health resources: A case study, Payesh 11 (6), 799-805

15. Rashidian A, Yousefi-Nooraie R, Azemikhah A, Heidarzadeh M, Changizi N, Mahta-Basir F, Motlagh ME. Perinatal care regionalization and geographical distribution model in the Islamic Republic of Iran. Hakim Health Sys Res. 2008; 11 (2): $1-11$

16. Mostafavi $\mathrm{H}$, Aghlmand $\mathrm{S}$, Zandiyan $\mathrm{H}$, Alipoori Sakha M, Bayati M, Mostafavi S. Inequitable Distribution of Specialists and Hospital Beds In West Azerbaijan Province. payavard. 2015; 9 (1): 55-66

17. Rezaei S, Nouri B. Evaluation of inequalities in the distribution of health resources by Gini coefficient and Lorenz curve: a case study in Kurdistan province from 2006 to 2013. SJKU 2016, 20(6): 1-11

18. Lawshe CH (1975). A quantitative approach to content validity1. Personnel psychology. 28(4):563

19.Ataolahi F BM, Abesi M, Mobasheri F, Khani $\mathrm{SH}$. Presentation of Ideal Planning Model for Hospital Beds Allocation in Shahid Mohammadi Hospital in Bandar Abbas. Journal of Health Care Management. 2014; 5(1):59-68.

20. Cardoso LT, Grion CM, Matsuo T, et al. Impact of delayed admission to intensive care units on mortality of critically ill patients: a cohort study. Critical Care. 2011; 15(1)

21. Jamali F, Sadrmousavi MS, Eshlaghi M. An introduction to hospital sites selection and design. Hospital. 2012; 11(2):87-98. 
22.Ahadnejad $M$, Ghaderi $H$, Hadian $M$, Haghighatfard P, Darvishi B, Haghighatfard E, et al. Location Allocation of Health Care Centers Using Geographical Information System: region 11 of Tehran. Journal of Fasa University of Medical Sciences. 2015; 4(4):463-74.

23. Council of Australian Therapeutic Advisory Groups.Managing Medicine Access Programs in Australian Hospitals.CATAG, 2015

24. Aghamohamadi S, Jahangiri K, Hajinabi K, Masoudi Asl I, Dehnavieh R. Foresight for Inpatient Beds in Hospitals of Iran: Vision 2035. jha. 2018; 21 (71): 23-36

25. Schofield DJ, Earnest A. Demographic change and the future demand for public hospital care in Australia, 2005 to 2050. Aust Health Rev2006; 30(4):507-15.

26. SH.Semnani (M.D), AA.Keshtkar (M.D). Assessing of equality on health care cost in Gorgan population laboratory study. J Gorgan Univ Med Sci. 2003; 5 (2): 53-59

27. Zahediasl M. Studying the relation of life quality and social capital. Quarterly journal of Social sciences. 2010; 17 (49): 1-29
28. Parsa Moghadam M, Yazdani M, Seyyedin A, Pashazadeh M. Optimal Site Selection of Urban Hospitals Using GIS Software in Ardabil City. J Ardabil Univ Med Sci. 2017; 16 (4): 374-388

29.Shafii M, Rashidian A, Nayeri F, Charrahi Z, Akbarisari A, Hamouzadeh P. Geographical Distribution and Presenting Initial Map of Hospital Services Regionalization for Mother and Infant in Tehran. Hakim Health Sys Res. 2012; 15 (1): $1-12$

30.Khabiri R, Khosravi A, Elahi E, Khodayari Moez E, Rashidian A. Maternal Health Care based on Iran' Multiple Indicator Demographic and Health Survey (IrMIDHS-2010). Hakim Health Sys Res. 2014; 17 (1): 67-77

31. Jafari F JA, Almodaresi S. Optimal spatial management using of fuzzy membership and overlaying functions and AHP model in GIS environment to clinics and hospitals site selection in Bandar Abbas. Urban Management Studies. 2016; 8 (27):55-68.

32. Navaee-Joghtaee M, Rajabzadeh M, BozorgiAmiri A. Locating and allocating health services with regard to cost and efficiency: case study Amol city. Journal of Health Administration. 2016; 19(63):21-33.

How to cite:

Abbasi A, Nasiri Pour A, Tabibi SJ, Raeisi P. Developing a Hospital Bed Distribution Model in Iran. Jorjani Biomedicine Journal. 2018; 6(2): 60-75. DOI: 10.29252/jorjanibiomedj.6.2.60 